\title{
Innovation processes in ecuadorian academia. Case: Escuela Politécnica Nacional
}

\section{Procesos de innovación en la academia ecuatoriana. Caso: Escuela Politécnica Nacional}

\author{
MORALES, Verónica ${ }^{1}$ \\ ROBALINO-LÓPEZ, Andrés \\ TOAPANTA, Priscila ${ }^{3}$
}

\begin{abstract}
This study presents a diagnosis of innovation processes at the Escuela Politécnica Nacional as a case among Higher Education Institutions (HEI) in the Ecuadorian context, and as part of its National Innovation System (NIS). For this purpose, there was built a theoretical model, which considers Capabilities, Results and Impacts (CRI) for quantifying innovation levels. This model was validated by the application of factorial analysis in order to know the interrelationships between variables, and, at the same time, to define which of them helps best to measure innovation.

key words: Innovation Level, Academic Innovation, Innovation Processes, Diagnosis

Resumen

Este estudio presenta un diagnóstico de procesos de innovación en la Escuela Politécnica Nacional como un caso de Instituciones de Educación Superior (IES) en el contexto ecuatoriano y como parte del Sistema Nacional de Innovación (SNI). Se construyó un modelo teórico, que considera Capacidades, Resultados e Impactos (CRI) para cuantificar los niveles de innovación, el cual fue validado mediante la aplicación de análisis factorial para conocer las interrelaciones entre variables y definir cuál de ellas ayuda mejor para medir la innovación.
\end{abstract}

Palabras clave: Nivel de innovación, Innovación académica, Procesos de innovación, Diagnóstico

\section{Introduction}

Innovation is a dynamic force that improves productivity and it is a necessary condition for the growth of an economy beyond the limits imposed by the availability of workforce (Hanel, 2015). Nowadays, in globalized markets, the ability to innovate is the key to success for organizations and it depends on a diversity of stakeholders. Thus, it is important to consider at least the triple helix model, which includes: government, productive sectors and academia (Sábato \& Botana, 1993; Etzkowitz \& Leydesdorff, 1995; Leydesdorff, 2012).

From the perspective of innovation, ecosystem models and stakeholders have been included, such as risk capital, entrepreneurs, companies, government, and universities (Budden \& Murray, 2017). Therefore, innovation

\footnotetext{
${ }^{1}$ Lecturer, Escuela Politécnica Nacional, Departamento de Estudios Organizacionales y del Desarrollo Humano, veronica.morales01@epn.edu.ec 2 Professor, Escuela Politécnica Nacional, Departamento de Estudios Organizacionales y del Desarrollo Humano, andres.robalino@epn.edu.ec ${ }^{3}$ Research Assistant, Escuela Politécnica Nacional, Departamento de Estudios Organizacionales y del Desarrollo Humano, lupe.toapanta@epn.edu. ACKNOWLEDGMENTS: The authors gratefully acknowledge the financial support provided by the Escuela Politécnica Nacional for the development of the project PIS-19-05.
} 
management is the management of ecosystem interactions to fulfill adaptation needs and organization survival (Escobar et al., 2017). In this way, academia is an important stakeholder for improving innovation ecosystems. However, Hernández et al. (2017) consider that not all Higher Education Institutions (HEls) have the conditions for promoting innovation processes. Then, if academia is not engaged in strengthening development of innovation processes, the innovation ecosystem could be fragile and powerless.

In Ecuador, the purposes of HEls are defined in the Ecuadorian Constitution (Art. 350), in which it is highlighted the need of a humanistic perspective about scientific-technological research and professional education in order to generate knowledge, culture and innovation for solving problems that affect the nation (AsambleaConstituyente, 2008). This denotes that HEls provide diverse knowledge services that can solve society problems, and that they can influence national development. Based on this, the National Secretariat of Science, Technology and Innovation of Ecuador, SENESCYT (2017) separates the mission of HEls in three aspects: i) knowledge generation; ii) higher level education (knowledge and skills transfer to students); and iii) knowledge transfer to society. It should be noted that knowledge is a basic element of these three missions of HEls; however, the relation HEl-society is particularly focused on the third mission, which is the gate to involve academia with other actors in the innovation ecosystem.

Academia is an essential actor in the construction of innovation ecosystems. For this reason, it is necessary to understand internal and external processes that support innovation. Moreover, Martínez et al. (2019) note that innovation for Ecuadorian HEls is still a big challenge to be considered in institutional strategies. In Ecuador, the Escuela Politécnica Nacional (EPN) is one of the major public universities of technology and its three main missions are to strengthen knowledge services such as publications, educational programs and other academic issues that support these types of processes (VIPS, 2017). The EPN is also an important actor of the national and regional innovation ecosystem. This study presents a diagnosis of the innovations processes at EPN through the construction of a theoretical model that includes Capabilities, Results and Impacts (CRI) as main factors for measuring innovation level in this institution.

\subsection{Innovation as a process}

Nowadays, the term innovation is used in most of the spaces and contexts. However, it is often misunderstood and overused. There is a consensus that innovation is a source of competitiveness. Therefore, it is necessary to propose a definition of innovation from a broad perspective that achieves its wide meaning. Kahn (2018) notes that innovation usually is conceptualized from one of these three perspectives: an outcome, a process, and a mindset.

Taking into account the outcome perspective, innovation is not limited to simple modifications in the production function as inventions, since it also implies the introduction of novelties in the market which leads to the improvement of competitiveness (Schumpeter, 1934; Hauschildt, 1991; Mulet, 2014). Note that this definition remarks innovation as a source of competitive advantages, which are key factors in the global challenge of competitiveness (Porter \& Stern, 2001).

The meaning of innovation is also manifested in cultural and individual aspects, which are presented in organizations and their members. According to Efrat (2014), investment is the most relevant factor to innovate. Despite of this, national and organizational culture influences locations where innovation flourishes, and individual characteristics of organization members motivate thinking towards innovation. Similarly, Kahn (2018) notes that favorable conditions to innovate need a cultural support and people engaged with design thinking and other empathetic mindset characteristics linked to creativity.

Innovation is also conceptualized as a process. Thus, Baregheh et al. (2009) affirms that innovation is not a discrete act; instead innovation is a multi-stage process where organizations transform ideas into new products, 
services or processes for competing with advantages in the market. Therefore, a multidisciplinary approach is required for building its definition. In this way, Robayo (2016) suggests that innovation should be studied as a process because its generation employs all operations of the organization. Furthermore, Arango et al. (2015) suggest that innovation outcomes should carry on benefits to organizations where innovative processes were implemented. The strong link between innovation outcomes and innovative processes is considered by OECD (2018) in the general definition of innovation of The Oslo Manual ( $4^{\text {th }}$ edition) as follows: "An innovation is a new or improved product or process (or combination) that differs significantly from the unit's previous products or processes and that has been made available to potential users (product) or brought into use by the unit (process)" (p. 32), note that unit refers to the actor or stakeholder responsible for innovations.

Moreover, organizations can not innovate in isolation. According to the triple helix model proposed by Sábato \& Botana (1993) and Etzkowitz \& Leydesdorff (1995), they need a set of relationships with other stakeholders (academia, government and productive sectors) for generating innovation networks. Carayannis et al. (2012) consider a quintuple helix than includes five systems: education, economy, policy, media and culture based, and natural environment. In a more sophisticate and specific approach, Budden \& Murray (2017) propose a quintuple helix as an innovation ecosystem for an innovation driven entrepreneurship (IDE) with five stakeholders: academia, government, corporations, risk capital and entrepreneurs. Furthermore, Machado et al. (2018), note that interaction among a broad set of stakeholders is fundamental for innovation. Similarly, Ramalho \& Vitale (2019) state that innovation comes from a process with different social actors where skills, knowledge and information are gathered and exchanged for solving technical, organizational, commercial or intellectual problems.

In brief, innovation is an outcome, a process and a mindset, at the same time. Innovation also is recognized by academia and society as a key factor for competitiveness and business success, which supports the regional and national progress. Innovation contemplates all organizational operations and requires the joint work of diverse stakeholders, which should be engaged in the development of an innovation ecosystem where culture and people include the essence of innovation as part of them. Hence, Robayo (2016) considers innovation as a process where knowledge, organizations, resources and market are involved.

\subsection{The role of HEls in innovation ecosystems}

HEls have always been considered institutions that create and transfer knowledge. Therefore, the strategic approach that guides the organizational culture of HEls to knowledge management should improve their competitive advantage and support innovation processes (Mejía et al., 2018). In this way, since the end of 20th century, their academic labor has had to be complemented with activities oriented to promote the relationship with industry, government and society (Serrano et al., 2017). Nowadays, HEls are usually concentrated in two innovation generation inputs: i) R\&D infrastructure, and ii) high qualified research personnel. However, their connection with actors of socio-economic environment is not clear. Thus, it is important to find a way to transfer the knowledge generated by HEls to society (Pinto \& Fernández-Esquinas, 2018). In brief, it is important to include the interaction with industry, government and the rest of society, as a role of HEls.

In consequence, McKelvey \& Zaring (2018) propose to deliver societal engagement of Universities through three knowledge-intensive services: i) research service that is linked particularly with academic staff, researchers and other HEls; ii) education service where students play the main role; and iii) societal interaction service that is linked to individuals and organizations. In Ecuador, SENESCYT (2017) defines three missions for HEls in order to deal with the challenges of knowledge society: i) knowledge generation; ii) high level education; and iii) knowledge transfer to society. These missions allow the interaction between HEls and society, and could influence the generation of innovations. Nunes \& Machado (2018) indicate that the third mission of HEls represents particularly their economic and social contribution to development. 
Collaboration with a big diversity of stakeholders is remarked by Huang \& Chen (2017) as a positive effect on the innovation performance of HEls. Prieto et al. (2019) consider Universities as a hub network that facilitates the construction of relationships between different innovation stakeholders. According to Guimón \& Salazar-Elena (2015), this kind of collaboration also benefits companies because of the possible advantages to obtain in terms of knowledge access, cost reductions and public policies incentives. Besides, Fritsch \& Slavtchev (2007) evidence that HEls joint effort of their public and private partners raises the knowledge production function. Thus, a healthy relationship of HEls with their innovation partners should generate a suitable ecosystem for innovation. Moreover, Paleari et al. (2015) state that the role of HEls should be associated to the society expectations. In this respect, nowadays, the role of HEls in the so-called "knowledge society" is not satisfied only by the generation of knowledge in academic units; but also requires strategic alliances with diverse public and private partners in order to innovate and support the development of society.

\subsection{Measuring innovation process at $\mathrm{HEls}$}

Quantification of social phenomena is attractive because of representation through numerical information gives the possibility to compare characteristics and to determine ranges between different analysis units. In consequence, this kind of social phenomena representation is usually considered more objective than others that do not have a factual character (Rottenburg \& Merry, 2015). Furthermore, indicators are a kind of quantification technology highly demanded in the field of governance because they generate numerical knowledge that is easy to evaluate, accessible and standardized (Merry, 2016). Likewise, indicators are a useful tool for monitoring, ordering, evaluating and comparing characteristics. In the case of innovation context, innovation processes measurements are used as instruments for decision-making, public policy formulation and strategies definition in order to promote innovation in public and private organizations (Lugones, 2009; Schwartz \& Guaipatín, 2014; RICYT, 2017).

According to Zizlavsky (2014), innovation is nowadays considered as a continuous and dynamic process that is much more complex to measure than a static task in organizations. There is a wide range of criteria and methods to evaluate innovation such as those proposed by Pezeshkan et al. (2016), Ivanova et al. (2017), Khedhaouria \& Thurik (2017), Carayannis et al. (2018) and Gault (2018), among others. In this context, OECD \& EUROSTAT (2018) conceive The Oslo Manual as a reference frame in continual evolution in its fourth edition. Here, there is reflected what can and should be measured in order to homogenize the information about innovation in organizations. A specific adaptation to the Latin American context is presented in The Bogotá Manual (RICYT, 2001), from which a practical methodology was developed by Camio et al. (2015) in order to obtain the innovation level index in organizations, taking into account three main categories: capabilities, results and impacts.

Otherwise, as noted by Ramos et al. (2017), Robalino-López et al. (2017a) and Robalino-López et al. (2019) for this type of process, contextualization is extremely important. Understanding cultural dynamics and the type of sector to which the organization belongs to is fundamental because it will have an impact on how much people identify with their organization and, therefore, on the consequences of this relationship, in regard to involvement, motivation and work satisfaction. Following this idea, Morales et al. (2019) propose a methodology for assessing innovation potential in organizations, contextualized to Ecuadorian reality. This methodology takes into account the instrument called CRI Model for measuring innovation level in organizations. This tool was designed by Robalino-López et al. (2017b) and it is applied in this study to the Escuela Politécnica Nacional as a specific case of HEls. 
Additionally, McKelvey \& Zaring (2018) assert that Universities organize processes for delivering knowledge intensive services to society. By reason of this specificity, innovation processes at HEls should be not analyzed like those in other organizations. On the other hand, Ortega \& Eguía (2011) propose that HEls could define innovation strategies joining their supply chain and the aggregated value of their main functions (Education, Research and Societal Engagement). Furthermore, Eguren \& Castán (2016) suggest that the value generated by an organization depends on the value provided by its value chain, which enables it to define its competitive advantage at a strategic level. Otherwise, Hernández et al. (2017) note a continual evolution of the dynamic innovation capabilities in the HEls. Despite of this, innovation is not developed in all of them. In consequence, it is necessary to understand the conditions that facilitate innovation in academic institutions. Hence, before measuring innovation processes at HEls, they must be understood. On that wise, one way to clarify how innovation processes works on HEls is through the analysis of their value and supply chains.

\section{Methodology}

The purpose of this study is the analysis of innovation processes at EPN as a case of a HEI in Ecuador. The analysis is focused on the understanding of the influence factors identified in the innovation processes at EPN, and not in the generalization of the results to a broader population. This study does not have a probabilistic approach, so the analysis units were not chosen randomly. In contrast, the analysis units have been carefully and intentionally selected to provide the greatest amount of information to approach the current situation of innovation processes at EPN. Hence, the poll of analysis units has been composed by 81 individuals classified into two groups: i) heads of laboratories, research centers and institutes, as they represent the academic staff responsible for teaching and research space in the HEI and their duties, and ii) administrative staff working in the Vice-Rectorate for Research (VIPS), due to this staff is continuously monitoring and giving administrative support in R\&D activities at EPN. Now, in order to enhance the information above, it is important to point out that the duties of the heads of laboratories, research centers and institutes include undergraduate management and postgraduate programs, as well as management of their relationship with society through consultancies, services and R\&D projects, which reinforce knowledge generation and contribute the development of innovation in academic and productive sector (VIPS, 2018).

\subsection{Design}

The instrument proposed by Robalino-López et al. (2017b) for measuring the innovation level in Ecuadorian organizations through their Capacities, Results and Impacts has been developed from the perspective of private companies. Then, it has been necessary to adapt it for the specific case of EPN, which, as a public HEI, has different kind of processes in comparison with those of private companies. Based on Ortega \& Eguía (2011), the study has developed an analysis of the value and supply chain to understand which processes influence the generation of innovation at EPN. Otherwise, there has been considered constructs definitions of CRI Model (Capabilities, Results and Impacts of innovation), according to the methodology proposed by Morales et al. (2019) for measuring the innovation potential in organizations. Then, the variables that should be included in the adapted instrument of CRI model for the case of EPN have been identified. Additionally, several semi-structured interviews to the academicians and researchers with experience in innovation processes have been conducted for analyzing the relevance of the variables of this model variables, within the context of HEls.

Also, a theoretical model has been developed with four abstraction levels: i) level cero represents the innovation level at the specific $\mathrm{HEI}$; ii) level one represents the current situation of innovation processes at the $\mathrm{HEI}$, in function of activities and resources that support the generation of innovation; iii) level two includes the categories of CRI Model (Capabilities, Resources and Impacts), and finally iv) level three includes the observed variables considered in the measurement instrument and separated in function of CRI Model categories. 
Considering this theoretical model, a structured survey with 45 variables to evaluate innovation has been developed. The survey is organized through three categories: Capabilities (25 variables), Results (10 variables) and Impacts (10 variables). Table 1 resumes the categories of variables included into the application of the CRI model in the study case. The survey uses a Likert scale with a range of 5 values for each affirmation, where 1 represents strongly disagree and 5 represents strongly agree (See Figures 2, 3 and 4).

Table 1

CRI model

\begin{tabular}{|c|c|c|c|}
\hline Category & Subcategory & Description & Variables \\
\hline \multirow{6}{*}{$\begin{array}{l}\text { Innovation } \\
\text { Capabilities }\end{array}$} & Information Sources & Ideas, internal and external data to generate innovation. & 10 \\
\hline & Financial Sources & Financial sources for innovation expenses. & 6 \\
\hline & $\begin{array}{l}\text { Investment and } \\
\text { Implementation Activities }\end{array}$ & $\begin{array}{l}\text { Activities supporting innovation through plans, programs, } \\
\text { and projects. }\end{array}$ & 9 \\
\hline & $\begin{array}{l}\text { Environmental Management } \\
\text { Activities to Promote } \\
\text { Innovation }\end{array}$ & $\begin{array}{l}\text { Activities helping to innovate through a suitable } \\
\text { management of environment. }\end{array}$ & 1 \\
\hline & $\begin{array}{l}\text { Organizational Management } \\
\text { Activities to Promote } \\
\text { Innovation }\end{array}$ & $\begin{array}{l}\text { Activities supporting innovations by the use of new and } \\
\text { better organizational practices. }\end{array}$ & 4 \\
\hline & Innovation Objectives & Objectives proposed to generate innovation. & 5 \\
\hline $\begin{array}{l}\text { Innovation } \\
\text { Results }\end{array}$ & Innovation Results & $\begin{array}{l}\text { Innovation outcomes generation (products, process, } \\
\text { markets or organizational models) through the proposed } \\
\text { innovation activities. }\end{array}$ & 10 \\
\hline \multirow{2}{*}{$\begin{array}{l}\text { Innovation } \\
\text { Impacts }\end{array}$} & Economic Impacts & $\begin{array}{l}\text { Consequences of changes in economic or commercial } \\
\text { aspects in the organization. }\end{array}$ & 3 \\
\hline & Social Impacts & $\begin{array}{l}\text { Application of corporate social responsibility, internal } \\
\text { responsibility and resources use. }\end{array}$ & 7 \\
\hline
\end{tabular}

Source: Adapted from Robalino-López et al. (2017b)

\subsection{Procedure}

Based on Camio et al. (2015) and Robalino-López et al. (2017b), a theoretical model was developed for measuring innovation processes in HEls. This model was used as a reference framework for improving the measurement instrument to be applied at EPN. Additionally, according to Ortega \& Eguía (2011) and the HEls missions defined by SENESCYT (2017), the value and supply chains of HEls were analyzed. This analysis has supported the identification of variables that should be included in the measurement instrument in order to quantify the situation of innovation processes at EPN. Then, the measurement instrument was implemented as a structured survey to be applied to the analysis unit.

After having summarized the responses of surveys and following the methodology proposed by Montoya (2007) and Yengle (2012), the correlation of variables has been calculated in order to do a first reduction of variables, according to the procedure of factor analysis. Later, a principal component analysis (PCA) has been applied to find the factors which capture the most information for each one of the measured categories (capabilities, results and impacts) that contributes to innovation at EPN. Finally, the results have been analyzed in order to understand the current situation of innovation processes at EPN and to identify their main influence factors. 


\section{Results}

An analysis of the internal EPN structure allows a better understanding of activities and processes that promote innovation. In this way, Ortega \& Eguía (2011) suggest identifying the supply and value chains in the organization taking into account its main actors, which, in the case of HEls, are suppliers' inputs, universities and beneficiaries of outcomes. The supply chain is composed by two services: i) the education service that transfers knowledge to future professionals; and ii) the research services that are seen as the production of knowledge. Moreover, the value chain in HEls is reflected in their activities related to social engagement, because education and research services should contribute to the development of society. Figure 1 illustrates the EPN as a case of HEls in the Ecuadorian context.

Figure 1

Components of Value and Supply Chain at Escuela Politécnica Nacional (EPN)

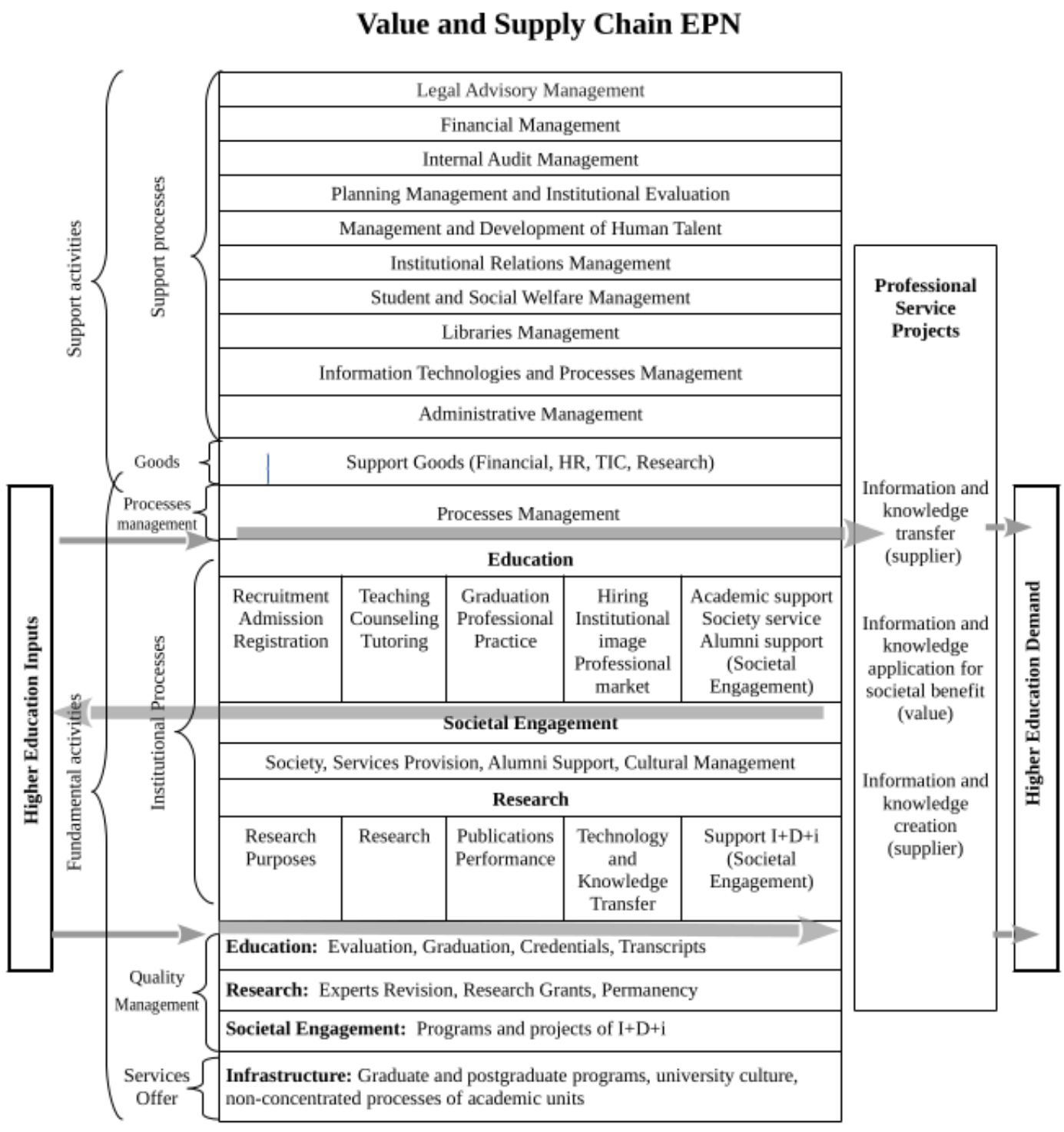

Source: Elaborated by authors, based on Ortega \& Eguía (2011) and EPN (2018) 


\subsection{Innovation capabilities}

Innovation capabilities are defined as a set of knowledge, competencies, resources and other issues that help to accomplish innovation organizational objectives (OECD \& EUROSTAT, 2018). Moreover, Innovation capabilities are the first category of the CRI model, and it is composed by six subcategories (see Table 1), which summarize the activities and processes that are needed for implementing innovation processes at HEls. Information sources (internal and external) are related to academic community, scientific publications, academic meetings and external institutions working on research and technological development. In this respect, it is important to include information about research and societal engagement projects coordinated by the Vice-Rectorate for Research (VIPS) or by other academic units, as those projects are innovation inputs. In contrast, the information sources that have not contributed to the development of innovation are composed by global indicators and activities related to the Institutional Relations Unit (DRI). This is explained because global indicators are too general information, and the DRI is an administrative unit related to the institutional image and it is not devoted to the improvement of partnerships. Figure $2 \mathrm{~A}$ shows the contribution of main information sources to innovation at EPN.

The main innovation financial source at EPN comes from the National Government, through the General State Budget and some funds from the National Secretariat of Science, Technology and Innovation (SENESCYT). Additionally, there are also some financial sources provided by self-management and international cooperation. Otherwise, no evidence has been found at EPN about financial sources for innovation originated from university associations, financial sector or business groups (see Figure 2B).

Most of the investment and implementation activities evaluated at EPN influence its innovation processes. Among them, R\&D projects are highlighted because they include different activities to support innovation (staff hiring, technological equipment investment, mobility of researchers, licenses or technology transfer agreements and technological training programs), as it is illustrated in Figure 2C. Other activities oriented to reinforce innovation processes are the improvement of teaching practices and research laboratories, as well as the design of new graduate and postgraduate programs. Additionally, the EPN has also implemented organizational modernization and quality assurance programs that aim to certify laboratories, but there have been revealed that they have only a partial or low influence on innovation processes.

The promotion of innovation at EPN through environmental management activities is still a challenge; there are only some isolated efforts in terms of recycling and waste management. So, this research has considered that these activities are not relevant for innovation development in this institution. Evaluation of organizational management activities has shown that EPN community usually exploits new knowledge of science and technology to improve services through their three main missions: education, research and societal engagement. However, this study has found that EPN staff perceive a low innovation promotion through institutional work conditions and that there have been problems with the use and availability of inputs for their usual tasks (see Figure 2D).

Innovation capabilities are also influenced by the fulfillment of innovation objectives (see Figure 2E). This study has found that main innovation objectives at EPN reflect the need of services' quality for increasing academic offer and for taking advantage of public policies in order to create innovation centers and university spaces that encourage students to generate new ideas and projects with innovative potential. However, the findings of this research evidence that the objective considering the creation of university extensions is not relevant to the development of innovation in the institution. 
Figure 4

Innovation Impacts Evaluation

\section{A. Information Sources}

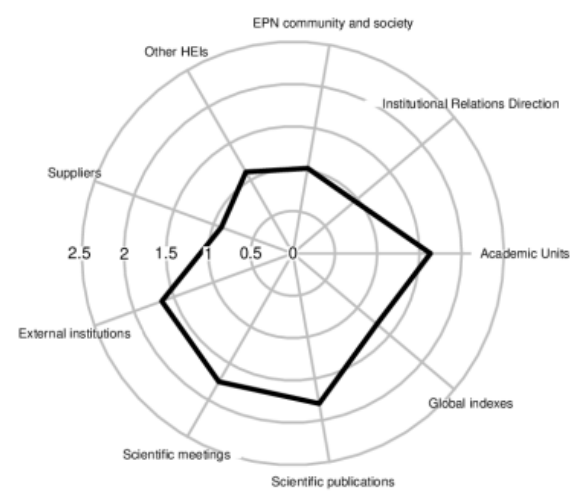

C. Investment and Implementation

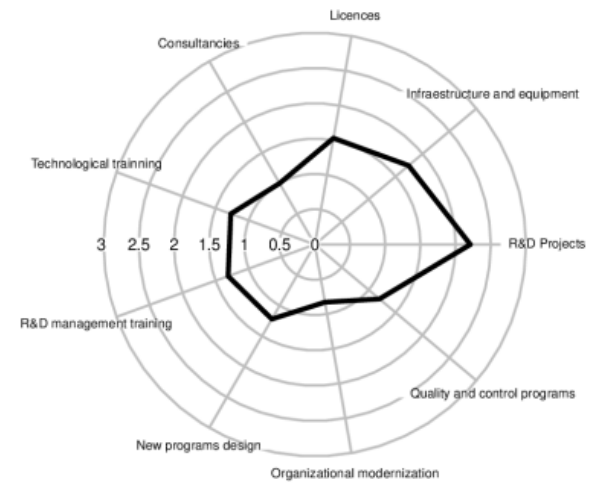

B. Financial Sources

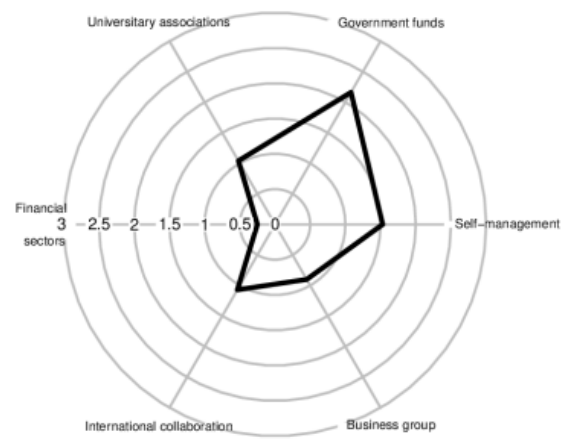

D. Organizational Management

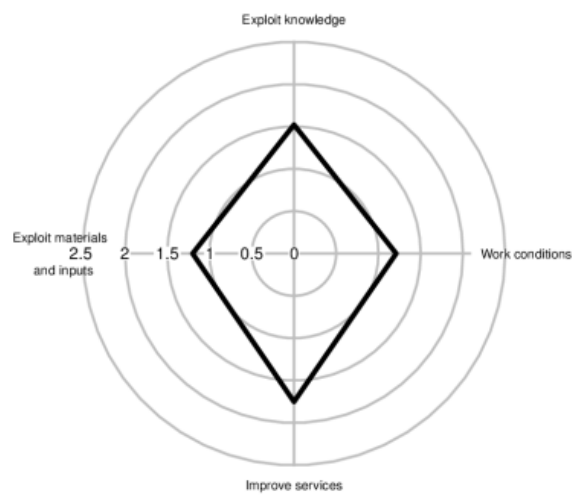

E. Innovation Objectives

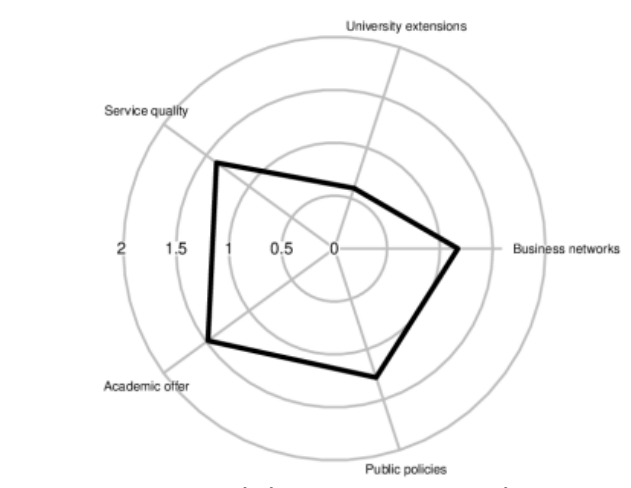

Innovation Capabilities Factors Evaluation

Source: Elaborated by authors

\subsection{Innovation results}

According to OECD \& EUROSTAT (2018), innovation results are linked to innovation objectives and are usually reflected on the effects of innovation activities. In this case, they were evaluated based on the outcomes offered by the university. These are the following: products, services and organizational processes. They are summarized in Figure 2. In this context, EPN has introduced 39 educational graduate and postgraduate programs as new academic services to society during 2017 (analyzed period). Other results focused on the certification of processes and services such as research and teaching laboratories. Additionally, new and improved 
organizational methods, commercial practices and support systems were enhanced to promote innovation at EPN.

Figure 3

Innovation Results Evaluation

\section{Innovation Results}

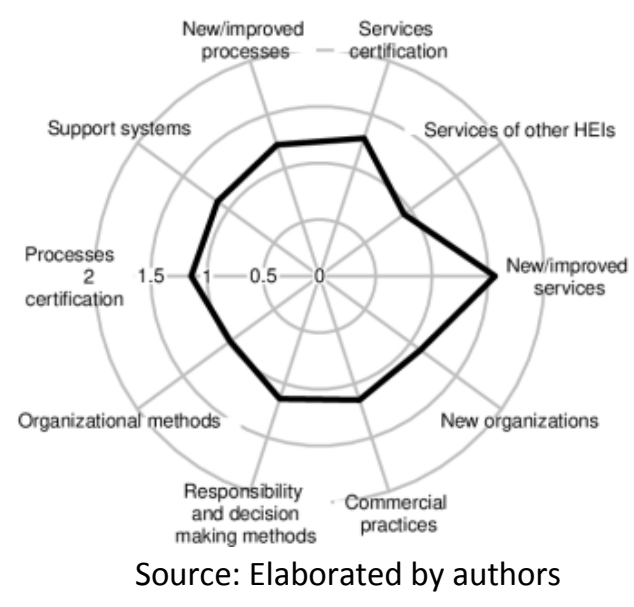

\subsection{Innovation impacts}

Finally, innovation impacts are evidenced from very diverse perspectives. In this case, they are reflected particularly in economic and social aspects (see Figure 4). Among them, the improvement of productivity is emphasized in terms of offered services. Other aspects that have shown a positive impact are life quality of its clients (university staff and external agents), labor relations, use of its resources (energy, water, paper, etc.), services quality and social responsibility. Otherwise, staff remuneration is not considered as an impact caused by innovation development in the institution because it is defined by a normative (Regulation of Career for Professors and Researchers of the National System of HEls). However, the perception of EPN community members indicates that these impacts are not visible; they are subjective. This situation can be explained by the fact that, at EPN, innovation activities of the university are not effective due to a poor relationship between society and HEls, as well as some organizational internal problems like a normative not adapted to promote innovation. 
Figure 4

Innovation Impacts Evaluation

\section{A. Economic Impact}

\section{B. Social Impact}
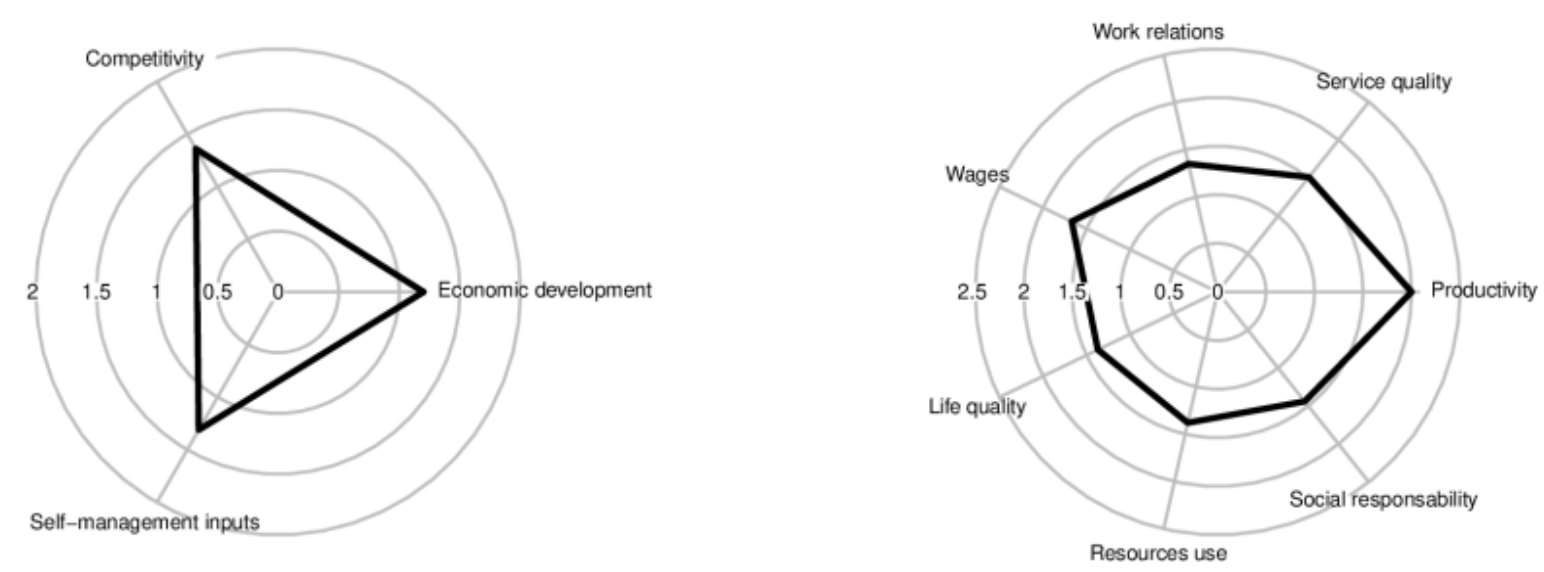

Source: Elaborated by authors

\section{Discussion and conclusions}

Innovation processes at EPN arise from initiatives of different academic units. In these spaces, academic staff and students usually consider publications, academic meetings and external institutions as main information sources for innovation. Therefore, R\&D projects with different approaches and scopes are undertaken, but only some of them seek to become "innovation driven projects". Additionally, other investment and implementation activities (e.g. licenses, technological equipment and academic education programs) are perceived as activities for supporting innovation at EPN.

Innovation results at EPN are reflected in new and improved services. Its perception in the analyzed unit highlights the following services: creation of new graduate and postgraduate programs, increment of academic publications in high impact journals, certifications of laboratories and, finally, participation in international initiatives for promoting the development of innovation ecosystems. Furthermore, results have shown that innovation impacts at EPN are particularly related to economic and social issues. Findings also evidenced the need to increase efforts for improving innovative activities like the improvement of laboratories equipment and infrastructure in order to carry out research projects for generating strong links between different innovation ecosystem actors; these links could lead to the design, implementation and evaluation of innovation policies.

Innovation processes measurement requires a multidisciplinary approach to not only obtain data, but also qualitative information concerning the innovation status in organizations. This work intends to contribute to the literature about innovation in HEls. However, it is important to point out that it bears certain limitations, such as the exploratory nature of this study, some access difficulties to information in laboratories and the sample size in order to obtain sufficient information about the perception of innovation processes at EPN.

The current state of innovation processes at EPN was implemented by using the CRI Model, since it has shown to be a useful tool for identifying main factors that affect innovation processes in an organization. Nevertheless, there are aspects related to creativity and adequate infrastructure for multidisciplinary work that have been not considered in the first version of the CRI model. Thus, potential development projects of innovation measurement models might be introduced at a later time. 
Finally, it is important to bring up that Ecuadorian HEls' innovation processes are limited by an innovation ecosystem with non-articulated relationships among its stakeholders. This condition is the consequence of reduced exchanges between productive sector and academia and due to a usually uncertain innovation policy for guiding a currently powerless National Innovation System. This situation has been strongly evidenced in the context of the COVID-19 worldwide crisis; Ecuador is one of the most affected countries and Ecuadorian HEls have not been able to contribute with innovative solutions to this emergence. As a consequence of this fact, the contribution of HEls to the resilience of the National System for Science, Technology and Innovation System is nowadays criticized.

\section{References}

Arango, B., Betancourt, J., \& Martínez, L. (2015). Implementación de herramientas para el diagnóstico de innovación en una empresa del sector calzado en Colombia. Revista de Administração e Innovação, 12(3), 310-330. https://doi.org/10.11606/rai.v12i3.100946

Asamblea Constituyente de la República del Ecuador. (2008, October 8). Constitución de la República del Ecuador. Registro Oficial. Órgano de la República del Ecuador,(449).

Baregheh, A., Rowley, J., \& Sambrook, S. (2009). Towards a Multidisciplinary Definition of Innovation. Management Decision, 47(8), 1323-1339. https://doi.org/10.1108/00251740910984578

Budden, P., \& Murray, F. (2017). A Systematic MIT Approach for Assessing “Innovation-Driven Entrepreneurship" in Ecosystems. Working Paper MIT's Laboratory for Innovation Science \& Policy, (36).

Camio, M. I., Romero, M. del C., \& Álvarez, M. B. (2015). Nivel de innovación en PYMES del sector software. Revista de Administração FACES Journal, 13(3). http://www.fumec.br/revistas/facesp/article/view/2019

Carayannis, E. G., Barth, T. D., \& Campbell, D. F. (2012). The Quintuple Helix Innovation Model: Global Warming as a Challenge and Driver for Innovation. Journal of Innovation and Entrepreneurship, 1(1), 2. https://doi.org/10.1186/2192-5372-1-2

Carayannis, E. G., Goletsis, Y., \& Grigoroudis, E. (2018). Composite Innovation Metrics: MCDA and the Quadruple Innovation Helix Framework. Technological Forecasting and Social Change, (131), 4-17. https://doi.org/10.1016/j.techfore.2017.03.008

Efrat, K. (2014). The Direct and Indirect Impact of Culture on Innovation. Technovation, 34(1), 12-20. https://doi.org/10.1016/j.technovation.2013.08.003

Eguren, M. D. L., \& Castán, J. M. (2016). Análisis taxonómico de la literatura: herramientas metodológicas para la gestión y creación de valor en la empresa. Innovar, 26(62), 41-56. https://doi.org/10.15446/innovar.v26n62.59387

Escobar, J. F., Cárdenas, M. F., \& Bedoya, I. B. (2017). De los sistemas a los ecosistemas de innovación. Espacios, 38(34), 20-38.

Escuela Politécnica Nacional del Ecuador. (2018). Resolución Administrativa (N. ${ }^{\circ}$ DTH-009-2018.73). Escuela Politécnica Nacional del Ecuador (EPN).

Etzkowitz, H., \& Leydesdorff, L. (1995). The Triple Helix - University-Industry-Government Relations: A Laboratory for Knowledge Based Economic Development. EASST Review, 14(1), 14-19. 
Fritsch, M., \& Slavtchev, V. (2007). Universities and Innovation in Space. Industry \& Innovation, 14(2), 201-218. https://doi.org/10.1080/13662710701253466

Gault, F. (2018). Defining and Measuring Innovation in All Sectors of the Economy. Research Policy, 47(3), 617622. https://doi.org/10.1016/j.respol.2018.01.007

Guimón, J., \& Salazar-Elena, J. C. (2015). Collaboration in Innovation between Foreign Subsidiaries and Local Universities: Evidence from Spain. Industry and Innovation, 22(6), 445-466. https://doi.org/10.1080/13662716.2015.1089034

Hanel, P. (2015). Économie de l'innovation: Innovation, croissance et productivité. In F. Bouchard, P. Doray, \& J. Prud'homme (Eds.), Sciences, technologies et sociétés de $A$ à $Z$ (p. 125). Presses de l'Université de Montréal. https://doi.org/10.4000/books.pum.4240

Hauschildt, J. (1991). Towards Measuring the Success of Innovations. Technology Management: The New International Language, , 605-608. https://doi.org/10.1109/picmet.1991.183747

Hernández, K. B., Vega, E. O., \& Acosta-Prado, J. C. (2017). Capacidad dinámica de innovación en instituciones de educación superior. Espacios, 38(1), 24-40.

Huang, M.-H., \& Chen, D.-Z. (2017). How Can Academic innovation Performance in University-Industry Collaboration Be Improved? Technological Forecasting and Social Change, (123), 210-215. https://doi.org/10.1016/j.techfore.2016.03.024

Ivanova, I., Strand, Ø., Kushnir, D., \& Leydesdorff, L. (2017). Economic and Technological Complexity: A Model Study of Indicators of Knowledge-Based Innovation Systems. Technological Forecasting and Social Change, (120), 77-89. https://doi.org/10.1016/j.techfore.2017.04.007

Kahn, K. (2018). Understanding Innovation. Business Horiwons,(61), 453-460. https://doi.org/10.1016/j.bushor.2018.01.011

Khedhaouria, A., \& Thurik, R. (2017). Configurational Conditions of National Innovation Capability: A Fuzzy Set Analysis Approach. Technological Forecasting and Social Change, (120), 48-58. https://doi.org/10.1016/j.techfore.2017.04.005

Leydesdorff, L. (2012). Triple Helix of University-Industry-Government Relations. Encyclopedia of Creativity, Invention, Innovation and Entrepreneurship, 14(1), 14-19. https://doi.org/10.2139/ssrn.1996760

Lugones, G. (2009). Módulo de capacitación para la recolección y el análisis de indicadores de innovación. BID.

Machado, H. V., Lazzarotti, F., \& Bencke, F. F. (2018). Innovation Models and Technological Parks: Interaction between Parks and Innovation Agents. Journal of Technology Management \& Innovation, 13(2), 104-114. https://doi.org/10.4067/S0718-27242018000200104

Martínez, G., Camargo, T., Ortiz, F., \& Izquierdo, D. (2019). Emprendimiento e innovación, un reto para la universidad ecuatoriana. Espacios, 40(21), 16-22.

McKelvey, M., \& Zaring, O. (2018). Co-Delivery of Social Innovations: Exploring the University's Role in Academic Engagement with Society. Industry and Innovation, 25(6), 594-611. https://doi.org/10.1080/13662716.2017.1295364 
Mejía, A. M., Vesga, A., \& Gaviria, M. M. (2018). Gestión del conocimiento científico en la Universidad de Antioquia: Integración de herramientas para la formulación de una estrategia. Innovar, 28(69), 71-84. https://doi.org/10.15446/innovar.v28n69.71697

Merry, S. E. (2016). The Seductions of Quantification: Measuring Human Rights, Gender Violence and Sex Trafficking. University of Chicago Press.

Montoya, O. (2007). Aplicación del análisis factorial a la investigación de mercados. Caso de estudio. Scientia et Technica, (35), 281-286.

Morales, V., Robalino-López, A., \& Almeida, C. (2019). Propuesta metodológica para la medición del potencial de innovación en las organizaciones ecuatorianas. Debates Sobre Innovación, 3(2), 1-14.

Mulet, J. (2014). La innovación, concepto e importancia económica. Sexto Congreso de Economía de Navarra.

Nunes, A. M., \& Machado, M. B. (2018). Enseñanza superior y sociedad: un estudio exploratorio sobre prácticas de la tercera misión en la Universidad Estadual de Campinas (Unicamp). Journal of Technology Management \& Innovation, 13(4), 94-104. https://doi.org/10.4067/S0718-27242018000400094

OECD. (2018). Rethinking Institutions for Development. OECD Publishing.

OECD, \& EUROSTAT. (2018). Oslo Manual 2018: Guidelines for Collecting, Reporting and Using Data on Innovation. OECD. https://doi.org/10.1787/9789264239012-en

Ortega, C., \& Eguía, I. (2011). Demanda y oferta de educación superior: Integración total de la cadena de valor y las cadenas de suministro. Economía y Administración (E\&A), 2(1), 21.

https://doi.org/10.5377/eya.v2i1.4348

Paleari, S., Donina, D., \& Meoli, M. (2015). The Role of the University in Twenty-First Century European Society. The Journal of Technology Transfer, 40(3), 369-379. https://doi.org/10.1007/s10961-014-9348-9

Pezeshkan, A., Smith, A., Fainshmidt, S., \& Amini Sedeh, A. (2016). National Business Systems and Firm Innovation: A study of Developing Economies. Journal of Business Research, 69(11), 5413-5418. https://doi.org/10.1016/j.jbusres.2016.04.147

Pinto, H., \& Fernández-Esquinas, M. (2018). What do Stakeholders Think about Knowledge Transfer Offices? The Perspective of Firms and Research Groups in a Regional Innovation System. Industry and Innovation, 25(1), 25-52. https://doi.org/10.1080/13662716.2016.1270820

Porter, M., \& Stern, S. (2001). Innovation: Location Matter. MIT Sloan Management Review, 42(4), 28-36.

Prieto, S., Montes, J., \& Taborda, J. (2019). A Hub-Based University Innovation Model. Journal of Technology Management \& Innovation, 14(1), 11-17. https://doi.org/10.4067/S0718-27242019000100011

Ramalho, M., \& Vitale, A. L. (2019). How to Stimulate an Entrepreneurial Ecosystem? Experiences of North American and European Universities. Innovar, 29(71), 11-24.

https://doi.org/10.15446/innovar.v29n71.76392

Ramos, V., Robalino-López, A., \& Franco, A. (2017). La congruencia de valores en organizaciones privadas, públicas y mixtas. CienciAmérica: Revista de Divulgación Científica de La Universidad Tecnológica Indoamérica, 6(3), 1-6.

RICYT. (2001). Manual de Bogotá. Normalización de Indicadores de Innovación Tecnológica en América Latina y el Caribe. 
RICYT., \& Albornoz, M. (Ed.) (2017). El estado de la ciencia. Principales indicadores de ciencia y tecnología iberoamericanos/interamericanos. RICYT.

Robalino-López, A., Ramos, V., Unda, X., \& Franco, A. (2017a). University's Contribution to Industries in the Creation of a Tool to Diagnose Innovation Management Processes. INTED 2017 Proceedings, , 2351-2360.

Robalino-López, A., Ramos, V., Unda, X., \& Franco, A. (2017b). Diseño de un modelo-herramienta para la medición de la innovación en la industria ecuatoriana. CienciAmérica: Revista de Divulgación Científica de La Universidad Tecnológica Indoamérica, 6(3), 76-82.

Robalino-López, A., Morales, V., Unda, X., \& Aniscenko, Z. (2019). Development and Innovation Processes: Application of a Methodology to Measure the Level of Innovation in the Ecuadorian Organizational Context. Brazilian Journal of Development, 5(6), 4550-4557.

Robayo, P. (2016). La innovación como proceso y su gestión en la organización: una aplicación para el sector gráfico colombiano. Suma de Negocios, (7), 125-140. https://doi.org/10.1016/j.sumneg.2016.02.007

Rottenburg, R., \& Merry, S. E. (2015). A World of Indicators: The Making of Governmental Knowledge through Quantification. In R. Rottenburg, S. E. Merry, S. J. Park, \& J. Mugler (Eds.), The World of Indicators (pp. 133). Cambridge University Press. https://doi.org/10.1017/CBO9781316091265.001

Sábato, J., \& Botana, N. (1993). La ciencia y la tecnología en el desarrollo futuro de América Latina. Arbor, (14), 21-43.

Schumpeter, J. A. (1934). The Theory of Economic Development. Oxford University Press.

Schwartz, L., \& Guaipatín, C. (2014). Ecuador: análisis del Sistema Nacional de Innovación. Hacia la consolidación de una cultura innovadora. BID.

SENESCYT. (2017). Aportes de la SENESCYT al debate de la Agenda 2035 (CIESPAL). SENESCYT.

Serrano, J., Acevedo, N., Castelblanco, J., \& Arbeláez, J. (2017). Measuring Organizational Capabilities for Technological Innovation through a Fuzzy Inference System. Technology in Society, (50), 93-109. https://doi.org/10.1016/j.techsoc.2017.05.005

Vicerrectorado de Investigación y Proyección Social. (2017). Rendición de Cuentas 2017 del Vicerrectorado de Investigación y Proyección Social (VIPS). Escuela Politécnica Nacional.

Vicerrectorado de Investigación y Proyección Social. (2018). Sistema de investigación, desarrollo, innovación y vinculación. Escuela Politécnica Nacional.

Yengle, C. (2012). Aplicación del análisis de componentes principales como técnica para obtener índices sintéticos de calidad ambiental. Scientia, 4(2), 145-153.

Zizlavsky, O. (2014). The Balanced Scorecard: Innovative Performance Measurement and Management Control System. Journal of Technology Management \& Innovation, 9(3), 210-222. https://doi.org/10.4067/S071827242014000300016

Esta obra está bajo una Licencia Creative Commons Attribución-NoCommercial 4.0 International

(cc) BY-NC 